\title{
Intestinal parasitic infection and body mass index among school children in oshodi lagos nigeria
}

\begin{abstract}
Background: Intestinal parasitic infections are still major public health problems in the world, particularly in developing countries. These parasitic infections have adverse effect on the health status of individuals particularly children.

Objective: The study is designed to determine the effect of nutritional status on the prevalence of intestinal parasites among the school children in Oshodi, Lagos State Nigeria between June and August 2014.

Methods: A total of consented 386 from seven public primary schools in Oshodi, $169(43.8 \%)$ boys and $217(56.2 \%)$ girls school children provided stool samples, their height and weight measured to calculate the body mass index (BMI) for the evaluation of the nutritional status of children and questionnaire were given to be completed. Their ages were between 3-14 years. Stool samples collected were examined using direct wet mount and the formal ether concentration technique. The BMI was classified based on children with normal weight and those that are under weight.

Results: Three species of intestinal parasitic infections were identified with overall prevalence of $58.3 \%$. The predominant parasites were Entamoeba histolytica (35.8\%), Entamoeba coli (22.0\%) and Ascaris lumbricoides (5.1\%). The prevalence among sex is $25.1 \%$ in males and $33.2 \%$ in females. The children with normal weight were $8.8 \%$, while underweight were $91.2 \%$. The relationship between infectivity and BMI was determined as normal weight $1.3 \%, \mathrm{P}=0.654$ and under weight $57 \% \mathrm{P}=0.845,(\mathrm{P}>$ $0.05)$.

Conclusion and Recommendations: This study has shown that intestinal parasitic infections are prevalent and have adverse effect on nutritional status of children in Oshodi, and there is need for improved nutritional, personal and environmental hygiene of these children so as to reduce the infection rate.
\end{abstract}

Keywords: intestinal parasites, nutritional statu, school children, oshodi, lagos state
Volume 2 Issue 2 - 2017

\author{
Ajayi MB,' Sani AH, ${ }^{2}$ Ezeugwu SMC,' Afocha \\ $\mathrm{EE},{ }^{\prime}$ Adesesan $\mathrm{AA}^{\prime}$ \\ 'Nigerian Institute of Medical Research, Nigeria \\ ${ }^{2}$ Mecure Health Care Ltd, Nigeria
}

Correspondence: Ajayi MB, Microbiology Division, Nigerian Institute of Medical Research (NIMR), Yaba Lagos, Nigeria, Email bankajayi@yahoo.co.uk

Received: December 14, 2016 | Published: February 20, 2017

\section{Introduction}

Intestinal parasitic infection is a major problem affecting the health of children in Africa. ${ }^{1}$ Approximately about 3.5 billion people are infected with intestinal parasites worldwide, the majority being primary school children. ${ }^{2}$ The endemicity have been indicated as the greatest single cause of worldwide disease and illness in children. ${ }^{3-5}$ Due to poor sanitary and tropical climate conditions, illiteracy and lack of portable drinking water and poverty the parasites become a significant public health challenge in sub-Saharan Africa.,

The nutritional status of a child is an important indicator of a child is overall health condition. ${ }^{7}$ Growth is the best global indicator of a child's well being. ${ }^{8}$ The most active phase of childhood is school age. ${ }^{9}$ Insufficient dietary intake, poor hygienic conditions and repeated parasitic infectious disease are the risk factors commonly known to give irregular growth pattern in children. ${ }^{8}$ Slower cognitive development, health complication and reduced quality of life have been linked to severe under nutrition in primary school children. ${ }^{10}$ Malnutrition is a common health problem of African school children due to inadequate food consumption and most importantly intestinal parasitic infections. ${ }^{11}$

Malnutrition occurs when there is deficiency or imbalance of certain important nutrients in an individuals' diet. ${ }^{12}$ Malnourished children are easily irritable, loose focus easily and fail to grow to their required height as reported by $\mathrm{WHO}^{13}$ when it projected that $29 \%$ of malnourished children from developing countries will have stunted growth due to poor nutrition in 2015. Malnutrition in children however is the consequence of a range of factors that are often related to poor food quality, insufficient food intake, and severe and repeated infectious diseases, or frequently a combination of the three. ${ }^{13}$

A huge loss to the economy as about 39 million disability adjusted life years (DALY's) are attributed to intestinal parasitic infection. ${ }^{14}$ Intestinal parasitic infections have also been associated with poor educational performance, physical weakness and stunting apart from morbidity and mortality in primary school children. ${ }^{15}$

Developing countries account for fifty percent of children infected annually with soil transmitted nematode and orally acquired helminthes and protozoa. ${ }^{16}$ It was estimated that more than 1 billion people are chronically infected with soil-transmitted worms, including Ascaris lumbricoides, Trichuris trichiuria, and hookworm infections.${ }^{17}$ The global prevalence of parasitic diseases is estimated to be 478 million children for Ascaris lumbricoides; 280 million for hookworms and 347 million children for. ${ }^{18-20}$ Several epidemiological studies indicated high prevalence rate of intestinal parasitic infections among Nigerian children. ${ }^{1,21-23}$ A recent study in Ogun State Southwest region of Nigeria indicates a prevalence of $25.8 \% .^{24}$

Therefore, the use of anthropometric index to evaluate the 
prevalence of under nutrition and the role of intestinal parasitic infection in the health condition of pupils in urban slum needs research attention. However, there is presently no effective and popular national or state school-based intestinal parasite control programme in Nigeria. There is also a dearth of information on the relationship between nutritional status and prevalence rate of intestinal parasitic infections amongst primary school pupils.

This study is intended to provide information on the basis for development of control programme at national, state and local government levels on the need for an effective primary school-based intestinal parasite eradication programme to be implemented as a school-based intervention.

\section{Materials and methods}

\section{Study area}

Oshodi Local Government Areas of Lagos State Nigeria covers land area of about $9.0 \mathrm{sqk}\left(9 \mathrm{~km}^{2}\right)$ and is located on latitude $06^{\circ} 25^{\prime} \mathrm{N}$ and longitude $03^{\circ} 27^{\prime} \mathrm{E}$. It shares border with the following Local Governments; Ikeja Local Government on the North, Onigbogbo Local Government on the North-East and Mushin Ajina Local Government in South-South East. It has two distinct seasons in the year, rainy (April to October) and dry season (November to March) with an average monthly temperature ranges between $34^{\circ} \mathrm{C}$ and $37^{\circ} \mathrm{C}$. It has a growing population of over 1,000,000 people/inhabitants with poor sanitary facilities, poor water management practices and indiscriminate disposal of waste materials. There are forty three public primary schools in the area with 28,400 pupils.

\section{Ethical consideration}

Ethical approval for the research work was given by Nigerian Institute of Medical Research (N.I.M.R) Ethical Committee Permission to have access to schools was given by Lagos State Ministry of Education (State Universal Basic Education Board). Informed consent from parents/guardians was gotten using parents/ teachers forum. Students enrolled for this study were duly informed and consented before sample collection.

\section{Sample collection}

A total of 249 samples were collected using Akingbade et al. ${ }^{24}$ method from students in Mafoluku, Oshodi and Shogunle public primary schools. ${ }^{24}$

Table I Prevalence of intestinal parasites and sex distributions among primary school children

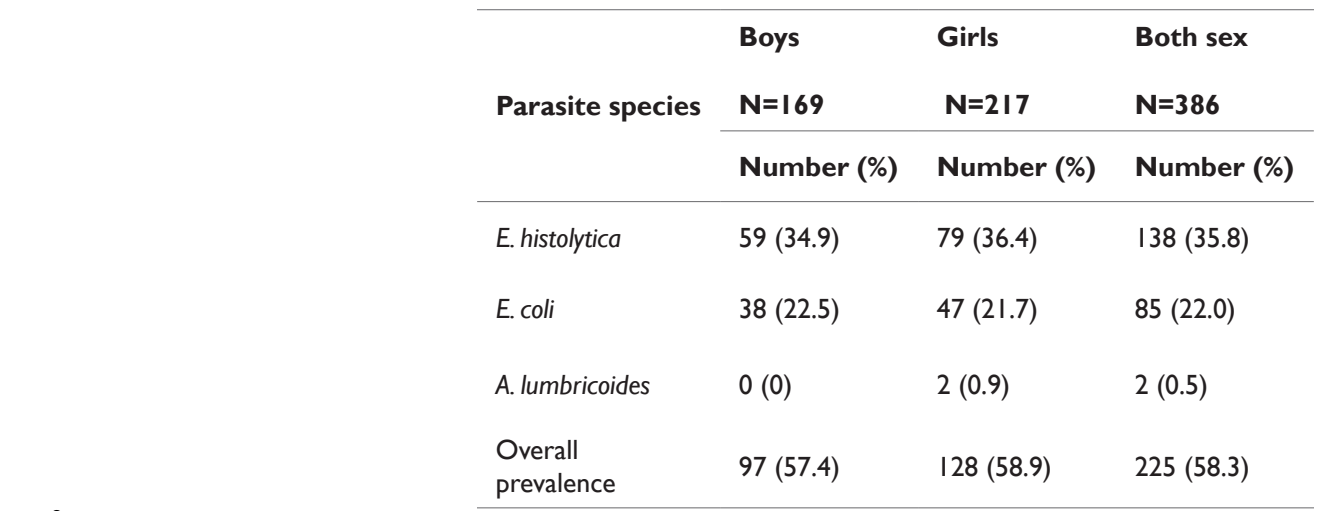

\section{Sample examination}

The stool was examined macroscopically for consistency, color, odour, presence of blood, mucus and presence of adult intestinal parasites (worms). Microscopic examination of the stool samples were carried out using saline and iodine mount method, Formalin ethyl acetate stool concentration technique (MINI PARASEP kit) was used to further identify cyst, egg or larvae of intestinal parasites.

\section{Nutritional status determination}

The body weight and height measurement to the nearest $0.1 \mathrm{~kg}$ and $0.1 \mathrm{~cm}$ respectively were taken for each pupil using an electronic weighing balance and a measuring tape to calculate anthropometric indicators (BMI).

\section{Statistical analysis}

The analysis was done using SPSS (Statistical Package for Social Sciences) version 17.0 to determine the differences in the prevalence of infection between ages and sexes and the relationship of infectivity of intestinal parasites and the BMI.

\section{Results}

A total of 386 students participated in this study 169 (43.8\%) are males with infection rate of $57.4 \%$ and $217(56.2 \%)$ females with infection rate of $58.3 \%$. E. histolytica had the highest prevalence of $35.8 \%$ from both sexes and E. coli having $22 \%$ while $A$. lumbricoides had a prevalence of $0.5 \%$ in female population. Table1. Table 2 shows the Prevalence of Intestinal Parasitic Infections among zones in Oshodi, Lagos, Nigeria, with the overall prevalence of intestinal parasitic infection of $58.3 \%$. The prevalence from Oshodi zone are $57.1 \%$ for Oshodi Primary School while $41.7 \%$ and $56 \%$ were from Afolabi and Local Government Primary Schools respectively. In Shogunle zone, Temidire Primary School had prevalence of $45 \%$. In Mafoluku zone, Aregbe Primary School presented a prevalence of $60.5 \%$ St. Paul Primary School had $64.3 \%$ while Mafoluku Primary School had $65.8 \%$. Table 3 showed the age distribution and prevalence of intestinal parasitic infections among the student. Ages 7-10 presented the highest prevalence of $24.9 \%$ while the lowest was observed 3-6 years $(8.0 \%)(\mathrm{P}>0.05)$. Table 4 shows the normal body mass index (BMI) and underweight BMI in relation to age groups and infectivity status of the students. $(\mathrm{p}<0.05)$. Age groups 7-10 and 11-14 were more of underweight as compared to Age group 3-6.

$\chi^{2}=1.03, \mathrm{DF}=3, \mathrm{P}=0.598, \mathrm{P}>0.05$ 
Table 2 Prevalence of intestinal parasitic infections among the zones in oshodi, lagos, nigeria

\begin{tabular}{|c|c|c|c|c|c|c|}
\hline & $\begin{array}{l}\text { Primary schools } \\
\text { examined }\end{array}$ & $\begin{array}{l}\text { Number } \\
\text { examined }\end{array}$ & $\begin{array}{l}\text { Number of } \\
\text { entamoeba } \\
\text { histolytica (\%) }\end{array}$ & $\begin{array}{l}\text { Number of } \\
\text { entamoeba coli (\%) }\end{array}$ & $\begin{array}{l}\text { Number of } \\
\text { ascaris }\end{array}$ & $\begin{array}{l}\text { Total number infected } \\
\%\end{array}$ \\
\hline \multirow{3}{*}{$\begin{array}{l}\text { Oshodi } \\
\text { Zone }\end{array}$} & Oshodi primary school & 21 & $7(33.1)$ & $4(19.0)$ & $\mathrm{I}(4.8)$ & $12(57.1)$ \\
\hline & Afolabi primary school & 36 & $8(22.2)$ & $7(19.4)$ & $0(0)$ & I5(4I.7) \\
\hline & $\begin{array}{l}\text { Local government } \\
\text { primary school }\end{array}$ & 25 & $7(28.0)$ & $7(28.0)$ & $0(0)$ & $14(56.0)$ \\
\hline \multirow[t]{2}{*}{$\begin{array}{l}\text { Shogunle } \\
\text { Zone }\end{array}$} & $\begin{array}{l}\text { Temidire primary } \\
\text { school }\end{array}$ & 60 & I7(28.3) & $10(16.7)$ & $0(0)$ & $27(45.0)$ \\
\hline & St. Paul primary school & 84 & $35(4 I .7)$ & $19(22.6)$ & $0(0)$ & $54(64.3)$ \\
\hline \multirow{3}{*}{$\begin{array}{l}\text { Mafoloku } \\
\text { Zone }\end{array}$} & $\begin{array}{l}\text { Mafoloku primary } \\
\text { school }\end{array}$ & 117 & $44(37.6)$ & $32(27.4)$ & $\mathrm{I}(0.9)$ & $77(65.8)$ \\
\hline & Aregbe primary school & 43 & $20(46.5)$ & $6(13.9)$ & $0(0)$ & $26(60.5)$ \\
\hline & Total & 386 & $138(35.8)$ & $85(22.02)$ & $2(5.1)$ & $225(58.3)$ \\
\hline
\end{tabular}

$\chi^{2}=13.48, \mathrm{DF}=12, \mathrm{P}=0.34 . \mathrm{P}>0.05$

Table 3 Age distribution and prevalence of intestinal parasitic infections among school pupils in oshodi, lagos

\begin{tabular}{|c|c|c|c|c|c|c|}
\hline $\begin{array}{l}\text { Age } \\
\text { group } \\
\text { (years) }\end{array}$ & $\begin{array}{l}\text { Number } \\
\text { examined }\end{array}$ & $\begin{array}{l}\text { Number of } E \text {. } \\
\text { Histolytica } \%\end{array}$ & $\begin{array}{l}\text { Number of } \\
\text { E.Coli (\%) }\end{array}$ & $\begin{array}{l}\text { Number of } A . \\
\text { Lumbricoides (\%) }\end{array}$ & $\begin{array}{l}\text { Number of mixed infection } \\
\text { (E. Histolytica \& E.Coli) (\%) }\end{array}$ & $\begin{array}{l}\text { Total number } \\
\text { infected } \%\end{array}$ \\
\hline 6-Mar & 44 & $22(50.0)$ & $9(20.5)$ & $0(0)$ & $\mathrm{I}(2.3)$ & $31(8.0 \%)$ \\
\hline I0-Jul & 206 & $63(30.6)$ & $32(15.5)$ & $\mathrm{I}(0.5)$ & $25(12.1)$ & $96(24.9 \%)$ \\
\hline $1|-| 4$ & 136 & $42(30.9)$ & $13(9.6)$ & $\mathrm{I}(0.9)$ & $16(\mid 1.5)$ & $56(47.4 \%)$ \\
\hline Total & 386 & & & & & $225(58.3)$ \\
\hline
\end{tabular}

$$
\chi^{2}=9.021, \mathrm{DF}=9, \mathrm{P}=0.42 . \mathrm{P}>0.05
$$

Table 4 Relationship between BMI and infectivity status

\begin{tabular}{|c|c|c|c|c|}
\hline \multirow{3}{*}{ Age (years) } & \multirow{3}{*}{$\begin{array}{l}\text { Normal BMI> I 8.5 - } 24.9 \\
\text { N (\%) }\end{array}$} & \multicolumn{2}{|c|}{ Infectivity status } & \multirow{3}{*}{ P-value } \\
\hline & & \multirow{2}{*}{$\begin{array}{l}\text { Non-infected } \\
\mathbf{N}(\%)\end{array}$} & \multirow{2}{*}{$\begin{array}{l}\text { Infected } \\
\mathbf{N}(\%)\end{array}$} & \\
\hline & & & & \\
\hline $3-6$ & $5(\mid 4.7)$ & $4(13.8)$ & $I(20.0)$ & \\
\hline $7-10$ & $17(50.0)$ & |3(44.8) & $4(80.0)$ & 0.654 \\
\hline I4-Nov & $12(35.3)$ & $12(4 \mid .4)$ & $0(0.0)$ & \\
\hline \multirow[t]{2}{*}{ Total } & $34(100)$ & $29(100)$ & $5(100)$ & \\
\hline & & \multicolumn{2}{|c|}{ Infectivity status } & \\
\hline \multirow[t]{2}{*}{ Age (years) } & ש. & Non-infected & Infected & P-value \\
\hline & $\mathbf{N}(\%)$ & $\mathbf{N}(\%)$ & $\mathbf{N}(\%)$ & \\
\hline 6-Mar & $39(11.1)$ & $9(6.8)$ & $30(13.6)$ & \\
\hline I0-Jul & $207(58.8)$ & $88(66.7)$ & $119(54.1)$ & 0.845 \\
\hline I4-Nov & $106(30.1)$ & $35(26.5)$ & $7 I(32.3)$ & \\
\hline Total & $352(100)$ & $132(100)$ & $220(100)$ & \\
\hline
\end{tabular}

Not significant i.e. $\mathrm{P}>0.05$ for both sides.

Citation: Ajayi MB, Sani AH, Ezeugwu SMC, et al. Intestinal parasitic infection and body mass index among school children in oshodi lagos nigeria. Adv Cytol Pathol. 20I7;2(2):44-49. DOI: I0.I5406/acp.20I7.02.000I5 


\section{Discussion}

This study revealed that the prevalence of intestinal parasitic infections from the different schools in Oshodi, Lagos Nigeria is high $(58.3 \%)$ compared to the work of Akingbade et al. ${ }^{24}$ in Ogun State, South-West Nigeria. ${ }^{24}$ This high prevalence could be related to lack of hand washing after the use of toilet, before and after eating and non washing of fruits before eating it. Poor sanitary condition, ill constructed drainages and unplanned urbanization are also factors that could have influenced the high prevalence in this urban setting The Local government is divided into three zones (Mafoluku, Oshodi and Shogunle). Oshodi Primary School had a prevalence of $57.1 \%$, while Afolabi Primary School was $41.7 \%$ from the Oshodi zone. Local Government Primary School had a prevalence of 56\% and Temidire Primary School was $45 \%$ from the Shogunle zone. A higher prevalence was recorded from Mafoluku zone with Aregbe Primary School having a prevalence of $60.5 \%$, St. Paul Primary School with a prevalence of $64.3 \%$ and Mafoluku Primary School 65.8\%.

This high prevalence of intestinal parasitic infection observed was in line with Chukwuma et al. ${ }^{21}$ in their study with primary school pupils in Anambra state, Nigeria and reported Obuno primary school $75 \%$, Umuji primary school $87.5 \%$ and Umuoghehi primary school, $95.5 \%$. Studies in India have also shown high prevalence ranging from $60 \%-70 \%$ in Gurajat ${ }^{22}$ Contrary to this high prevalence of intestinal parasitic infection, Akingbade et al. ${ }^{24}$ had a lower prevalence of $25.8 \%$ in Abeokuta Ogun state, Nigeria while Mordi et al. ${ }^{25}$ reported $0.7 \%$ prevalence in Edo state. This low prevalence was also seen in the study conducted by Alison et al. ${ }^{26}$ in Uganda.

In this study, Entamoeba histolytica, Entamoeba coli and Ascaris lumbricoides were the intestinal parasites detected. Mixed infections also observed. Entamoeba histolytica was more prevalent parasite detected and it is known to be the most medically significant amoeba species of man. Infection from species of amoeba occurs when there is ingestion of contaminated foods containing cyst of the parasite. ${ }^{27}$ This study shows that $E$. histolytica $(35.8 \%)$ is the predominant intestinal parasites and this finding is in agreement with previous studies done by Okonko et al..$^{28}$ where a prevalence of $51.7 \%$ was reported. Mordi et al. ${ }^{25}$ reported a higher value of $94 \%$. Some findings in Nigeria are in disagreement with these high prevalences. Akingbade et al..$^{24}$ reported prevalence of $19.4 \%$ for E. histolytica, Omudu et al. ${ }^{29}$ reported $20.3 \%$, in Imo state Okolie et al. ${ }^{20}$ reported a prevalence of $19.1 \%$. In this study, Entamoeba coli and Ascaris lumbricoides presented a prevalence of $22.8 \%$ and $0.5 \%$ respectively. Entamoeba coli being the second predominant intestinal parasite in this study agreed with the study of Akingbade et al. ${ }^{24}$ having $(25.8 \%)$ but completely in contrast with the findings of Egwari et al. ${ }^{30}$ where there was no report of Entamoeba coli in their study.

The low prevalence of Entamoeba coli and Ascaris lumbricoides compared with Entamoeba histolytica is in disagreement with the studies of Akingbade et al..$^{24}$ that reported a higher prevalence of $54.8 \%$ of Ascaris lumbricoides, Odu et al. ${ }^{31}$ also reported $57.4 \%$ prevalence in their study. The present of E. histolytica and E. coli are clear indications of poor environmental sanitation, poor personal hygiene, lack of hand washing culture and nail sucking among the students used for this study.

Infections were more common in girls (58.9\%) than boys $(57.4 \%)$, previous studies done by Ekpenyong EA et al. ${ }^{32}$ in Enugu agrees with this finding and this implies that the prevalence was sex determinant in conformity with Akingbade et al. ${ }^{24}$ in Abeokuta Ogun state, but the finding disagrees with the studies of Okonko et al., ${ }^{23}$ Chukwuma et.al. ${ }^{21}$ who reported that intestinal parasitic infections were more common in boys than girls. Many other reports such as those of Baldo et al., ${ }^{33}$ Adeyeba et al..$^{34}$ also showed report of higher rate of infections in boys than girls. Tiedaece in Ethiopia reported higher prevalence in boys $(28.1 \%)$ and $(24.3 \%)$ in girls, other studies conducted among school children in Nepal indicated that both sexes were equally exposed. ${ }^{35,36}$ In Nigeria, Awolaju et al. ${ }^{1}$ reported no significant difference between intestinal parasitic infection and sex in Osun state. This is in agreement with Nkengazong et al. ${ }^{37}$ in Cameroon who reported that there was no significant difference in the prevalence of parasite to the sexes in Kotto Barombi and in Marumba.

In our study, we found out that those children between 3-6 years had higher prevalence $(72.7 \%)$ compared to other age groups; 7-10 years and $11-14$ years which had $58.7 \%$ and $52.9 \%$ respectively. Previous study done in Nigeria by Ekpenyong et al. ${ }^{32}$ in Enugu agrees with this finding. Also, Akingbade et al. ${ }^{24}$ in Ogun state agrees with the high prevalence in this group. This may be due to the fact that their immunity to parasite has not been fully developed for this age group. In the contrary, Odu et al. ${ }^{31}$ reported that intestinal parasitic infections are not age dependent. Low body immune system, lack of potable drinking water, poor sanitary condition and habits like nail biting and sucking might be attributed to the high prevalence in this study and others..$^{38}$

Anthropometry has become a practical tool for evaluating the nutritional status of populations, particularly of children in developing countries $^{39}$ and nutritional status is the best indicator of the global well-being of children. ${ }^{40}$ This study revealed that intestinal parasitic infection have been linked to malnutrition which compromise the nutritional status of children ( $\mathrm{P}>0.05)$. The high prevalence rate of children from malnutrition and anthropometric measurement from this study shows children with normal weight were $34(8.8 \%)$ while children that are underweight were 352(91.2\%). Previous reports had showed a close association between intestinal parasitism and malnutrition. ${ }^{41-43}$

A possible interpretation is that both intestinal parasitism and malnutrition are of public health importance. This present study recorded a high degree of malnutrition among the children in the study those with normal BMI>18.5-24.9 had lower infectivity rate compared to abnormal BMI (underweight) $<18.5$ children having higher infectivity rate. The $\mathrm{P}$ value for normal weight was 0.654 $(\mathrm{P}>0.05)$ and that of underweight children was $0.845 \quad(\mathrm{P}>0.05)$. This findings agreed with the studies of other investigators such as Adekunle, ${ }^{44}$ Croptom \& Nesheim, ${ }^{42}$ Chandrasena et al., ${ }^{45}$ Carvalhocosta et al., ${ }^{46}$ Nematian et al. ${ }^{47}$

\section{Conclusion and recommendations}

This study has shown that intestinal parasites are still highly prevalent among children in Oshodi an urban setting in Lagos. The data obtained from this study provides base line information on the adverse effect of intestinal parasite on the nutritional status of children which is alarming. The need to take serious personal, communal and environmental hygiene would contribute to the reduction of this high prevalence and this will in no small measure increase the physical development and well-being of children. Government at all levels must have an effective regular school based deforming programme as an intervention for Controlling neglected tropical diseases. 


\section{Acknowledgements}

None.

\section{Conflict of interest}

The author declares no conflict of interest.

\section{References}

1. Awolaju BA, Morenikeji OA. Prevalence and intensity of intestinal parasites in five communities in south-west Nigeria. African Journal of Biotechnology. 2009;8(18):4542-4546.

2. WHO. Drugs used in parasitic disease Geneva. WHO publication; 1999. $136 \mathrm{p}$.

3. Curtale F, Pezzoti P, Sharbini AL, et al Knowledge, perceptions and behavior of mothers towards intestinal helminthes in upper Egypt: Implication for control. Health Policy Plan. 1998;13(4):423-432.

4. Garzon M. Parasites- A holistic approach. Capital university of integrated medicine, USA: Springer; 2003.

5. Steketee RW. Pregnancy, Nutrition and parasitic diseases. J Nutr. 2003;133(5 Suppl 2):1661-1667.

6. Nokes C, Bundy DA. Does helminth infection affect mental processing and educational achievement. Parasitol Today. 1994;10(1):14-18.

7. Prentice A. Nutritional requirements for growth, pregnancy and lactation: the keneba experience. South African Journal of Clinical Nutrition. $1993 ; 6: 33-38$.

8. Assis AM, Prado MS, Barreto ML, et al. Childhood stunting in Northeast Brazil: the role of Schistosoma mansoni infection and inadequate dietary intake. Eur J Clin Nutr. 2004;58(7):1022-1029.

9. Kuczmarski RJ, Ogden CL, Guo SS, et al. 2000 CDC growth charts for the united states: methods and development. Vital Health Stat. 2002;11(246):1-190.

10. Waterlow IC, Buzina R, Keller W, et al. The presentation and use of height and weight data for comparing the nutritional status of groups of children under the age of 10 years. Bull World Health Organ. 1977;55(4):489-498.

11. Walker A, Walker B. Moderate to mild malnutrition in African children of 10-12 years: roles of dietary and non-dietary factors. Int J Food Sci Nutr. 1997;48(2):95-101.

12. Blossner, M, Mercedes De Onis, Pruss Ustun, et al. Malnutrition: quantifying the health impact at national and local levels. Geneva, world health organization. geneva : world health organization; $2005.43 \mathrm{p}$.

13. World health organization. Prevention and control of schistosomiasis and soil-transmitted helminthiasis. World Health Organ Tech Rep Ser. 2005;912(i-vi):1-57.

14. Chan MS. The global burden of intestinal nematode infections - fifty years on. Parasitol Today. 1997;13(11):438-443.

15. Nokes C, Grantham MC, Gregors SM, et al. Parasitic helminth infection and cognitive function in schoolchildren. Proc Biol Sci. 1992;247(1319):77-81.

16. Glew RH, Conn CA, Bhanji R, et al. Survey of the growth characteristics and body composition of Fulani children in a rural hamlet in northern Nigeria. J Trop Peadiatr. 2003;49(5):313-322.

17. De Silva NR, Brooker S, Hotez PJ, et al. Soil-transmitted helminth infections: updating the global picture. Trends Parasitol. 2003;19(12):547551.
18. Bethony J, Brooker S, Albonico $\mathrm{M}$, et al Soil-transmitted helminth infections: ascariasis, trichuriasis, and hookworm. Lancet. 2006;367(9521):1521-1532.

19. Musgrove P. Investing in health: The 1993 World Development Report of the World Bank. Bull Pan Am Health Organ. 1993;27(3):284-286.

20. Okolie BI, Okonko IO, Ogun AA, et al. Incidence and Detection of Parasite Ova in Appendix from Patients with Appendicitis in South-Eastern, Nigeria. World Journal of Agricultural Sciences. 2008;4(S):795-802.

21. Chukwuma MC, Ekejindu IM, Agbakoba NR, et al. The prevalence and risk factors of geohelminth infections among primary school children in ebenebe town, Anambra State, Nigeria. Middle-East Journal of Scientific Research. 2009;4(3):211-215.

22. Das NC, Russel S, Trivedi GK, et al. Prevalence of intestinal parasites in jamnagar and okhla towns - Gujarat. J Commun Dis. 1981;13(1):67-70.

23. Alli JA, Okonko IO, Oyewo AJ, et al. Prevalence of intestinal parasites among palm wine drinkers in ibadan metropolis. Researcher. 2011;3(11):11-16.

24. Akingbade OA, Akinjinmi AA, Ezechukwu US, et al. Prevalence of Intestinal Parasites among Children with Diarrhea in Abeokuta, Ogun State, Nigeria. Researcher. 2013;5(9):66-73.

25. Mordi RM, Ngwodo POA. A study of blood and gastro-intestinal parasites in Edo State. African Journal of Biotechnology. 2007;6(19):22012207.

26. Alison ME, James AGW, Moses, et al Screening for intestinal helminth infection in a semi-urban cohort of Pregnant women in Uganda. Trop Doc. 2004;34(1):27-28.

27. Ajero CM, Nwoko BEB, Nwoke EA, et al. Human amoebiasis: Distribution and burden; and the nigerian environment. International Science Research Journal. 2008;1(2):130-134.

28. Okonko IO, Soleye FA, Amusan TA, et al. Detection and Prevalence Intestinal Parasites In Patients In Abeokuta, South-Western, Nigeria. World Applied Sciences Journal. 2009;7(9):1183-1187.

29. Omudu EA, Amuta EU, Feese JI. The prevalence of intestinal helminths in children with different socio-economic background in Markurdi, Nigeria. Niger Soc Parasitol. 2004;20:71.

30. Egwari LO, Iwuanyanwu S, Ojelabi CI, et al. Bacteriology of Sachet Water Sold in Lagos, Nigeria. East Afr Med J. 2005;82(5):235-240.

31. Odu NN, Maxwell SN, Nte AR, et al. Helminthiasis among school children in rural communities in Rivers State, Nigeria. Nigerian J Microbiol. 2013;24:2219-2223.

32. Ekpeyong EA, Eyo JE. Prevalence in intestinal heminths infections among schooling children in tropical semi urban communities. Animal Research International. 2008;5(1):804-810.

33. Baldo ET, Belizairo VY, Deleon WU, et al. Infection status of intestinal parasites in children living in residential institutions in metro manila, the philippines. Korean J Parasitol. 2004;42(2):67-70.

34. Adeyeba OA, Akinlabi AM. Intestinal parasitic infections among school children in rural community, South-West Nigeria. Nigerian Journal of Parasitology. 2002;23(1):11-18.

35. Rai SK, Rai G, Hirai K, et al. The health system in Nepal - an introduction. Environ Health Prev Med. 2001;6(1):1-8.

36. Ishiyama S, Ono K, Rai SK. Study of enteropathogen and its predisposingfactors in suburban public school children in Kathmandu Nepal. Nepal Medical College Journal. 2001;3:5-9.

37. Nkengazong L, Njiokou F, Teukeng F, et al. Reassessment of endemicity level of urinary schistosomiasis in the Kotto-Barombi focus (South West Cameroon) and impact of mass drug administration (MDA) on the parasitic indices. Journal of Cell and Animal Biology. 2009;3(9):159-164. 
38. Alli JA, Kolade AF, Okonko IO, et al. Prevalence of intestinal nematode infection among pregnant women attending antenatal clinic at the University College Hospital, Ibadan, Nigeria. Advances in Applied Science Research. 2011;2(4):1-13.

39. Hakeem R, Shaikh AH, Asar F. Assessment of linear growth of affluent urban Pakistani adolescents according to CDC 2000 references. Ann Hum Biol. 2004;31(3):282-291.

40. Onis Mde, Frongillo EA, Blossner M. Is malnutrition declining? An analysis of change in levels of child malnutrition since 1980. Bull World Health Organ. 2000;78(10):1222-1223.

41. Tsuyuoka R, Bailey JW, Nery Guimaraes AM, et al. Anaemia and intestinal parasitic infections in primary school students in Aracaju, Sergipe, Brazil. Cad Saude Publica. 1999;15(2):413-421.

42. Crompton DWT, Nesheim MC. Nutritional Impact of intestina helminthiasis during the human life cycle. Annu Rev Nutr. 2002;22:35-59.
43. Quihui Cota L, Valencia M, Crompton D, et al. Prevalence and intensity of intestinal parasitic infections in relation to nutritional status in Mexican schoolchildren. Trans R Soc Trop Med Hyg. 2004;98(11):653-659.

44. Adekunle L. Intestinal parasites and nutritional status of Nigerian children. Afr J Biomed Res. 2002;5:115-119.

45. Chandrasena TG, De Alvis AC, De Silva LD, et al. Intestinal parasitosis and the nutritional status of veddah children in Sri Lanka. Southeast Asian J Trop Med Public Health. 2004;35(2):255-259.

46. Carvalho Costa FA, Goncalves AQ, et al. Giardia lamblia and other intestinal parasitic infections and their relationships with nutritional status in children in Brazilian Amazon. Rev Inst Med trop S Paulo. 2007;49(3):147-153.

47. Nematian J, Gholamrezanezhad A, Nematian E. Giardiasis and other intestinal parasitic infections in relation to anthropometric indicatorsof malnutrition: a large, population-based survey of schoolchildren in Tehran. Ann Trop Med Parasitol. 2008;102(3):209-214. 